\title{
Efficient Electrochemical Removal of Ammonium in Wastewater Using Various Cathodes and $\mathrm{a} \mathrm{Ti} / \mathrm{IrO}_{2}$ Anode
}

\section{ALFA-SIKA MANDE SEYF-LAYE ${ }^{1,2,3 *}$, AKPATAKU KOSSITSE VENYO 2,3, TCHAKALA IBRAHIM $^{2}$, DJANEYE-BOUNDJOU GBANDI², BAWA LEMAN MOCTAR ${ }^{2}$ and CHEN HONGHAN ${ }^{1}$}

\author{
'Beijing Key Laboratory of Water Resources \& Environmental Engineering, \\ China University of Geosciences (Beijing), Beijing 100083, P.R. China. \\ ${ }^{2}$ Laboratory of Applied Hydrology and Environment, University of Lome, BP. 1515, Togo. \\ ${ }^{3}$ Faculty of Science and Technology, University of Kara, BP. 404, Togo. \\ ${ }^{*}$ Corresponding author E-mail: seyf009@yahoo.ca
}

http://dx.doi.org/10.13005/ojc/360122

(Received: August 04, 2018; Accepted: February 18, 2020)

\begin{abstract}
The removal of ammonium in wastewater by an electro-oxidation method using $\mathrm{Cu}, \mathrm{Fe}$ and alloy $\mathrm{Cu} / \mathrm{Zn}$ as cathodes and $\mathrm{Ti} / \mathrm{IrO}_{2}$ as anode were investigated. The effects of the various operating parameters, including, electro-oxidation duration, temperature, salt $(\mathrm{NaCl})$ and electrode types on the ammonium removal efficiency from synthetic wastewater and real wastewater in batch EC process, were also investigated. The results showed that the maximum removal efficiency was achieved at a current density of $16 \mathrm{~mA} / \mathrm{cm}^{2}$, at a pH of 5.1 , temperature of $30^{\circ} \mathrm{C}$ and $0.5 \mathrm{~g} / \mathrm{L} \mathrm{NaCl}$. Among tested materials, $\mathrm{Cu} / \mathrm{Zn}$ cathode showed the highest ammonium removal rate. The results revealed that the ammonium was removed and $0.2 \mathrm{mg} / \mathrm{L}$ of nitrate and $0.023 \mathrm{mg} \mathrm{N} / \mathrm{L}$ of nitrite were found. Finally, the really wastewater was tested at $40^{\circ} \mathrm{C}$ in presence of $\mathrm{Cu} / \mathrm{Zn}$ cathode/ $\mathrm{Ti} / \mathrm{IrO}_{2}$ anode with a current density of $18.32 \mathrm{~mA} / \mathrm{cm}^{2}$ and the result indicates that electro-oxidation is very efficient and was able to achieve ammonium removal $(99.99 \%)$, and COD removal (38\%) in 30 min. During the treatment concentrations of nitrate, nitrite and phosphorous were not detected in the effluent after 30 minute. The ammonia removal followed pseudo-first-order kinetics. The electrochemical process can be applied successfully as a final polishing step, or as an alternative method to biological nitrification.
\end{abstract}

Keyword: Electrochemical, Nutrient removal, Electrodes, $\mathrm{Ti} / \mathrm{IO}_{2}$, Chemical oxygen demand.

\section{INTRODUCTION}

Water pollution by nutrients is a historical and ever-growing concern in developed and developing countries alike. The ammonium in the water was usually generated from a process of incomplete degradation of organic matter. Ammonium was generated from the reaction of iron-containing minerals with nitrates. This was an excellent indicator of water pollution polluted by organic waste that came from agricultural, domestic or industrial. High concentration ammonium could

This is an Open Access article licensed under a Creative Commons license: Attribution 4.0 International (CC- BY). Published by Oriental Scientific Publishing Company @ 2018

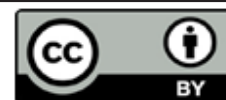


promote eutrophication, which was fatal to aquatic life and an obstacle to the disinfection of water sources ${ }^{8,16}$. Ammonium is not toxic, but could cause several problems such a decrease in the efficiency of the chlorine treatment and the development of microorganisms responsible for flavors and odors. The oxidation of ammonium would produce nitrite, which could be oxidized to nitrate. Meanwhile, nitrate could cause serious health problems in humans such as the "blue baby syndrome" in infants, liver damage and cancer ${ }^{6,20}$. The main reason for the increase in nitrate in groundwater was mainly attributed to the abusive use of nitrogen fertilizer ${ }^{12}$. Nitrate in the solution had some properties such as high solubility, less capacity for precipitation and adsorption, so it was difficult to remove nitrate from solution. Thus, electrochemical methods have been evaluated for this purpose ${ }^{2,14}$ and several electrodes such as $\mathrm{Cu}, \mathrm{Fe}, \mathrm{Zn}, \mathrm{Pt} / \mathrm{Ir}$ and $\mathrm{Au}$. However, some electrodes such as $\mathrm{Cu}$ and $\mathrm{Fe}$ were recognized as promoters for the nitrate reduction. The aim of this work was to find the best conditions to reduce the concentration of ammonium.

\section{EXPERIMENTAL}

\section{Material}

Only analytically graded chemicals were used without further treatment. Stock ammonium solutions were prepared with distilled water from ammonium chloride.

\section{Analytical Method}

At given time intervals, liquid samples were withdrawn from the feed tank. Ammonium concentrations were determined by a flow injection analyzer (Lachat-QC8000, Hach, Loveland, CO, USA) using a salicylate spectrophotometric method. Nitrate $\left(\mathrm{NO}_{3}^{-}-\mathrm{N}\right)$, nitrite $\left(\mathrm{NO}_{2}^{-}-\mathrm{N}\right)$ and phosphorous concentrations were determined by ion chromatography (DX-600, DIONEX Co., Sunnyvale, USA). The detection limit for each analyte was $0.1 \mathrm{mg} / \mathrm{L}$; the standard deviation for replicate samples was $\pm 10 \%$. The portable multiparameter meters (HQ40d, Hach, Loveland, CO, USA) was used to measure $\mathrm{pH}$ while COD was analyzed according to the APHA methods ${ }^{1}$.

\section{EXPERIMENTAL}

A $613 \mathrm{~mL}$ dacryl plastic rectangular tank, with dimensions of $6.5 \times 6.5 \mathrm{~cm}$ square base and a height of $14.5 \mathrm{~cm}$ with two plate electrodes (1 anode and 1 cathode) with an area of $6 \times 14 \mathrm{~cm}^{2}$ was used as shown in Fig. 1. The plates were placed vertically in the tank and separated by a distance of $2 \mathrm{~cm}$. Cu, Fe and $\mathrm{Cu} / \mathrm{Zn}$ plates were used as a cathode while $\mathrm{Ti} / / \mathrm{IO}_{2}$ plates were used as anode. Alternating electrodes were connected to a digital DC power supply (containing amperemeter and voltmeter was used to measure the current intensity passing through the circuit and the applied potential difference respectively), characterized by $10 \mathrm{~A}$ for current intensity and a range of $0-40 \mathrm{~V}$ for voltage in monopolar mode. Synthetic ammonium solutions (with concentration of $50 \mathrm{mg} \mathrm{N} / \mathrm{L}$ ) were used. At the beginning of each run the ammonium solution of $50 \mathrm{mg} \mathrm{N} / \mathrm{L}$ concentration was fed into the cell and solution of $0.5 \mathrm{~g} / \mathrm{L} \mathrm{NaCl}$ (as electrolyte) was added to it to increase the solution conductivity. Each run was timed starting with the DC power supply switching on. Thermostatic bath shaker was used to set the temperature. Finally, the better material electrode was used to treat the real wastewater.

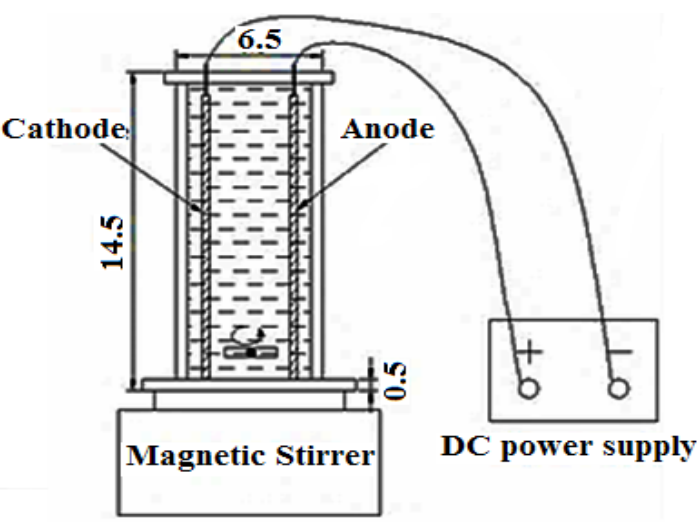

Fig. 1. Laboratory scale of reactor system

\section{Electrocoagulation Procedure}

A volume of $300 \mathrm{~mL}$ of synthetic waste solution was used for each run and mixed with an appropriate concentration of $\mathrm{NaCl}$ which was used to increase the conductivity. The prepared solutions were put into an electrolytic cell. $\mathrm{NaOH}$ or $\mathrm{HCl}$ solutions were used to adjust the $\mathrm{pH}$ of the synthetic waste solution. Direct current was used for an electrolysis run during $60 \mathrm{~min}$. via two electrodes. At every $10 \mathrm{~min}$. interval, a volume of 10 $\mathrm{mL}$ of the solution was sampled and filtered for the determination of residual concentrations of $\mathrm{NH}_{4}^{+}, \mathrm{NO}_{3}$ and $\mathrm{NO}_{2}^{-}$. The location of the drawn samples was kept 
constant for each run. Before each run, the electrodes as cathode were cleaned with sandpaper to remove impurities and toxic layer, and then were washed with $15 \% \mathrm{w} / \mathrm{v}$ of $\mathrm{HCl}$ solution in order to remove any adhering scales or oxides. After this process, all the electrodes were cleaned with distilled water and dried until the electrodes are used again.

\section{RESULTS AND DISCUSSION}

\section{Effect of different electrodes on ammonium removal without $\mathrm{NaCl}$}

As shown in Fig. 2, the electrolysis was carried out when used different electrodes such as $\mathrm{Cu} ; \mathrm{Fe}$ and alloy $\mathrm{Cu} / \mathrm{Zn}$ as cathode without adding $\mathrm{NaCl}$, the ammonium removal efficiency was $94.4 \%$, concentrations of $\mathrm{NO}_{3}^{-}-\mathrm{N}$ was $0.53 \mathrm{mg} \mathrm{N} / \mathrm{L}$ and $\mathrm{NO}_{2}^{-}-\mathrm{N}$. It was probably because $\mathrm{Cu}$ could inhibited the hydrogen evolution and its seemed that $\mathrm{Cu}$ had more negative potential that was approximately $1.2 \mathrm{~V}$ which could inhibit the amount of hydrogen production, and then affected the ammonium removal and nitrate formation ${ }^{19}$, the phenomenon was because less hydrogen would lead to the low selectivity of ammonium, and then Cu electrode was difficult to subside in the solution.

The ammonium removal efficiency was $98.7 \%$ with the $\mathrm{Fe}$ as electrode. The higher removal with iron electrode could be due to the greater donating electron. Nitrite- $\mathrm{N}$ was an intermediate product and could be oxidized to nitrate. $\mathrm{NO}_{2}^{-}-\mathrm{N}$ concentration with $\mathrm{Fe}$ and $\mathrm{Cu}$ as electrodes was lower and the reduction of ammonium to nitrate was relatively higher. Because the reaction was slow during the early $30 \mathrm{~min}$. due to that the presence of ferrous ions would affect the reaction when the concentration of dissolved oxygen was low in the solution. When the reaction was carried out in 40 min ferrous compounds were oxidized at a rate that was enough to precipitate hydrated ferric hydroxide at a higher oxygen concentration. Meanwhile, the nitrate concentration sharply increased to $1.43 \mathrm{mg}$ $N / L$ and decreased finally Fig. 2. The utilization of $\mathrm{Ti} / \mathrm{IrO}_{2}-\mathrm{Pt}$ as anode favored considerably elimination of ammonium due to the high oxidation ability. In the present experiment, Fe cathode was more useful for ammonium removal and nitrate reduction than $\mathrm{Cu}$ electrode without $\mathrm{NaCl}$.
Ammonium removal efficiency was $99.28 \%$ using alloy $\mathrm{Cu} / \mathrm{Zn}$ as cathode (Fig. 2). The removal efficiency of ammonium and the formation of nitrate increased significantly at the first time and finally decreased. The mechanism of electrolytic ammonia reduction was complex. Without $\mathrm{NaCl}$ addition, the oxidation of ammonium and accumulation of nitrate during electrolytic process could be attributed to the alloy $\mathrm{Cu} / \mathrm{Zn}$ cathode prossessed good corrosion resistance, and zinc had good electro-activity and $\mathrm{Cu}$ exhibited good activity of electro-reduction. As a result that high ammonium removal efficiency was expected when using the alloy $\mathrm{Cu} / \mathrm{Zn}$ as electrode. According to the the research of ${ }^{22}$ the ammonium removal efficiency was better than using $\mathrm{Cu} / \mathrm{Zn}$ as electrode. The nitrate concentration obtained from ammonium oxidation was $1.1 \mathrm{mg} \mathrm{N} / \mathrm{L}$. According to the results, it could be concluded that $\mathrm{Cu} / \mathrm{Zn}$ as cathode was more suitable than $\mathrm{Fe}$ and $\mathrm{Cu}$ in the absence of $\mathrm{NaCl}$.

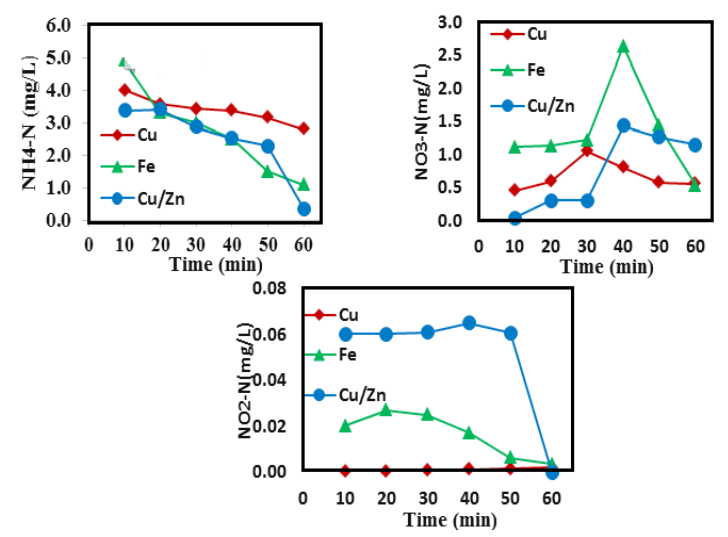

Fig. 2. Effect of different electrodes on removal of ammonium ( $\left.\mathrm{Co}=50 \mathrm{mg} / \mathrm{L} ; \mathrm{NaCl}=0 \mathrm{~g} / \mathrm{L} ; \mathrm{pH}=5.1 ; 16 \mathrm{~mA} / \mathrm{cm}^{2}\right)$

\section{Effect of different electrodes on ammonium} removal with $\mathrm{NaCl}$

The elimination of ammonium and formation of nitrite and nitrate was shown in Fig. 3 during electrolysis using $\mathrm{Cu}$, Fe and alloy $\mathrm{Cu} / \mathrm{Zn}$ as cathode in the presence of $0.5 \mathrm{~g} / \mathrm{L} \mathrm{NaCl}$. The ammonium removal efficiency was $97.44 \%$, then $0.053 \mathrm{mg} \mathrm{N} / \mathrm{L}$ and $2.5 \mathrm{mg} \mathrm{N} / \mathrm{L}$ nitrite and nitrate were formed in $60 \mathrm{~min}$. when using Cu electrode respectively. While ammonium was completely remove in $40 \mathrm{~min}$ and 50 min. using respectively $\mathrm{Cu} / \mathrm{Zn}$ and Fe electrodes. Comparing to the result obtained by $\mathrm{Fe}$ and $\mathrm{Cu} / \mathrm{Zn}$ cathodes, the ammonium removal efficiency was lower and the nitrate concentration in treated solution was higher with $\mathrm{Cu}$ electrode than those with $\mathrm{Fe}$ and $\mathrm{Cu} / \mathrm{Zn}$ cathode. Nitrite concentration was lower 
with $\mathrm{Fe}$ electrode and higher with $\mathrm{Cu}$ and $\mathrm{Cu} / \mathrm{Zn}$ electrodes. This could be explained by the fact that the $\mathrm{Cu} / \mathrm{Zn}$ electrode had a higher potential which would promote hydrogen evolution reaction in the vicinity of cathode. As shown in Fig. 3, it was clearly that ammonium removal rate greatly increased with the addition of $\mathrm{NaCl}$. It was probably due to the relatively high oxidation ability of the $\mathrm{Ti} / / \mathrm{rO}_{2}-\mathrm{Pt}$ anode used in the present study, with which more hypochlorite ion was formed during electrolysis. In addition, the fact that the iron would donate large number of electrons would promote the electrolysis system for removal of ammonium and nitrite-N and nitrate- $\mathrm{N}$.

In the presence of chloride ion, the hypochlorite ion was formed and then oxide ammonium to nitrite or nitrate. Hence, the indirect oxidation of ammonium played an importance role during the electrochemical method ${ }^{4}$. The concentration of nitrate sharply increased to $0.28 \mathrm{mg} \mathrm{N} / \mathrm{L}$ until $40 \mathrm{~min}$. and finally decreased, whereas the concentration of nitrite was $0.046 \mathrm{mg} \mathrm{N} / \mathrm{L}$ using Cu/Zn electrodes. The results were not consistent with the previous study which concluded that the presence of chloride ion in the solution did not change the essential nature of the nitrate reduction.

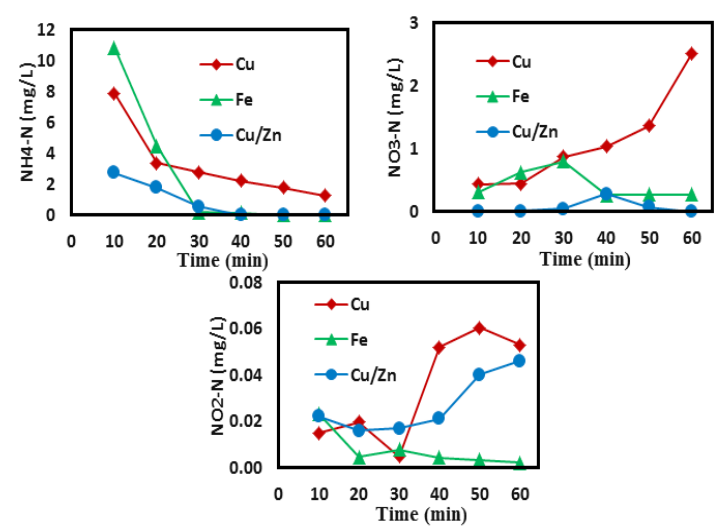

Fig. 3. Effect of different electrodes on removal of ammonium (Co=50 mg/L; $\mathrm{NaCl}=0.5 \mathrm{~g} / \mathrm{L} ; \mathrm{pH}=5.1 ; 16 \mathrm{~mA} / \mathrm{cm}^{2}$ )

\section{Effect of temperature on removal of ammonium} Cu electrode

It was confirmed that removal efficiency of ammonium was kept at $98 \%$ where as the formation of nitrate sharply increased along with the temperature increased from $20^{\circ} \mathrm{C}$ to $40^{\circ} \mathrm{C}$ Fig. 4. The ammonium removal rate was lowest with $\mathrm{Cu}$, while that was highest with $\mathrm{Fe}$ and $\mathrm{Cu} / \mathrm{Zn}$ cathode. This could be explained at the first by the fact that the copper slowly dissolved in the ammonium solution containing oxygen. Secondly, the previous studies have shown that the voltammetry study of $\mathrm{Cu}$ would produce more negative potential and finally would make less evolution of hydrogen ${ }^{19}$. That peak would be attributed to that the oxidation/ reduction of $\mathrm{Cu}_{2} \mathrm{O}$ to $\mathrm{Cu}$ species. Our result have also found that copper was less selective for the ammonium removal ${ }^{10}$. However, the products of ammonium like nitrite and nitrate were formed during electrolysis process. The concentration of nitrate produced from ammonium was $0.035,2.05$ and 1.27 $\mathrm{mg} \mathrm{N} / \mathrm{L}$ with $20^{\circ} \mathrm{C}, 30^{\circ} \mathrm{C}$ and $40^{\circ} \mathrm{C}$ respectively in 60 min. (Fig. 4). The reason was due to the low $\mathrm{pH}$ found at the end of the experiments. Low concentration of nitrite was observed.

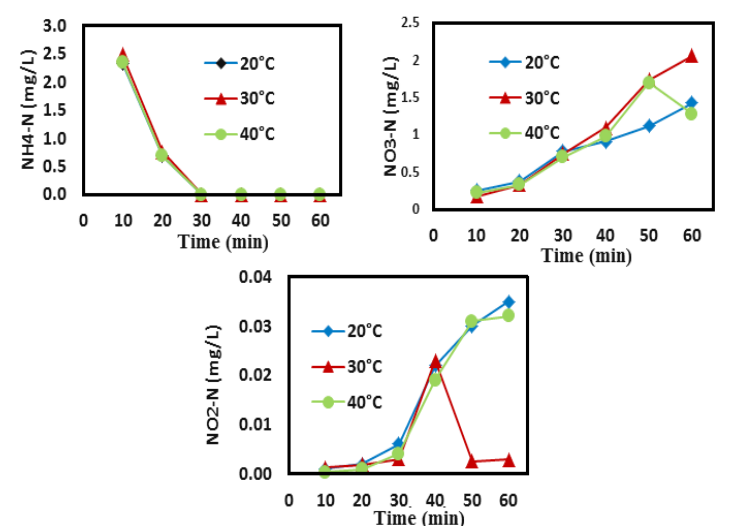

Fig. 4. Effect of Temperature on removal of ammonium using Cu electrode $\left(\mathrm{Co}=50 \mathrm{mg} / \mathrm{L} ; \mathrm{NaCl}=0.5 \mathrm{~g} / \mathrm{L} ; \mathrm{pH}=5.1 ; 16 \mathrm{~mA} / \mathrm{cm}^{2}\right)$

\section{Fe electrode}

The results showed the ammonium removal efficiencies were $98.8 \%, 99.6 \%$ and $98.92 \%$ in $20 \mathrm{~min}$. when temperature were $20^{\circ} \mathrm{C}, 30^{\circ} \mathrm{C}$ and $40^{\circ} \mathrm{C}$, respectively (Fig. 5). The effect of $30^{\circ} \mathrm{C}$ on ammonium removal was found to be better than those of $20^{\circ} \mathrm{C}$ and $40^{\circ} \mathrm{C}$ because the formation of nitrate was significant when the temperature were $20^{\circ} \mathrm{C}$ and $40^{\circ} \mathrm{C}$ during the $50 \mathrm{~min}$. and then decreased. This phenomenon could be explained by the fact that iron was corroded due to the increase in $\mathrm{pH}$ in the solution. The production of hydrogen gas and ferrous hydroxides raised the $\mathrm{pH}$, which continued until entire solubility of ferrous hydroxide and deposition of iron hydroxide on the surface of the metal as a film form smothering the corrosion reaction. The results explained why ${ }^{18}$ found faster nitrate removal rate for oxide coated $\mathrm{Fe}^{0}$. Ammonium was completely removed in 30 minute. This could 
be explained by the fact that the final $\mathrm{pH}$ was 6.0 , 7.18 and 7.07 at $20^{\circ} \mathrm{C}, 30^{\circ} \mathrm{C}$ and $40^{\circ} \mathrm{C}$, respectively. The oxidation of ammonium to ammonia gas with iron electrode was due to the high $\mathrm{pH}^{7}$. The nitrate concentration was $1.87 \mathrm{mg} \mathrm{N} / \mathrm{L}, 1.69 \mathrm{mg} \mathrm{N} / \mathrm{L}$ and $1.84 \mathrm{mg} \mathrm{N} / \mathrm{L}$ at $20^{\circ} \mathrm{C}, 30^{\circ} \mathrm{C}$ and $40^{\circ} \mathrm{C}$, respectively (Fig. 5). That demonstrated the nitrate concentration increased with the decrease of temperature. Increasing the temperature resulted in the increase of chloride ion, which indicated the presence of anions could inhibit the reduction of nitrate because that would decrease the active area of the electrode surface ${ }^{9,17}$. The concentration of nitrite was detected $0.040 \mathrm{mg}$ $\mathrm{N} / \mathrm{L}, 0.046 \mathrm{mg} \mathrm{N} / \mathrm{L}$ and $0.039 \mathrm{mg} \mathrm{N} / \mathrm{L}$ at $20^{\circ} \mathrm{C}, 30^{\circ} \mathrm{C}$ and $40^{\circ} \mathrm{C}$, respectively (Fig. 5). The presence of nitrite increased the catholic current, which indicated that the nitrite reduction rate with iron electrode was faster than nitrate reduction rate.
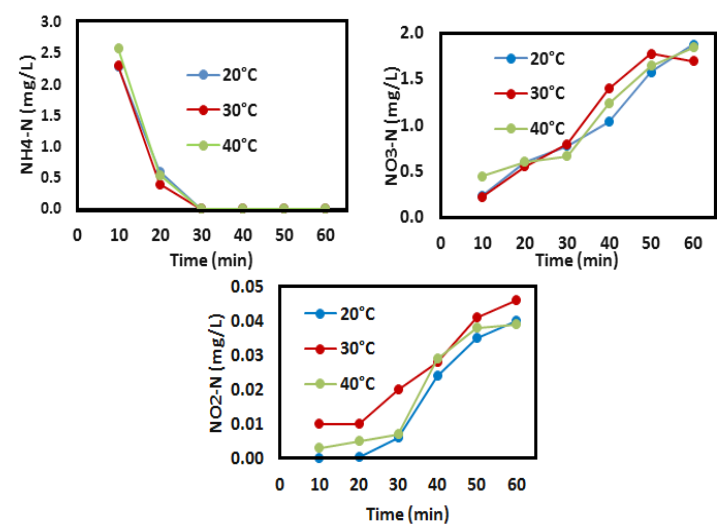

Fig. 5. Effect of temperature on removal of ammonium using Fe electrode $\left(\mathrm{Co}=50 \mathrm{mg} / \mathrm{L} ; \mathrm{NaCl}=0.5 \mathrm{~g} / \mathrm{L} ; \mathrm{pH}=5.1 ; 16 \mathrm{~mA} / \mathrm{cm}^{2}\right)$

\section{$\mathrm{Cu} / \mathrm{Zn}$ electrode}

According to the results, the ammonium removal efficiencies were $98.08 \%, 100 \%$ and $99.5 \%$ in only $20 \mathrm{~min}$. at $20^{\circ} \mathrm{C}, 30^{\circ} \mathrm{C}$ and $40^{\circ} \mathrm{C}$, respectively (Fig. 6). The percentage of ammonium decreased when temperature increased from $20^{\circ} \mathrm{C}$ to $40^{\circ} \mathrm{C}$. This could be explained by the changes of $\mathrm{pH}$ in the different reactions during the oxidation of ammonium. The final $\mathrm{pH}$ was $7.13,7.05$ and 7.08 at $20^{\circ} \mathrm{C}, 30^{\circ} \mathrm{C}$ and $40^{\circ} \mathrm{C}$, respectively. These results were in accordance with previous studies that reveal the optimum $\mathrm{pH}$ was between 7 and $9^{3,10,11}$. It appeared that oxidation of ammonium was strong under alkaline conditions due to that $\mathrm{ClO}_{3}{ }^{-}$agent had a lower oxidability. This explained why the elimination of ammonium was faster at $30^{\circ} \mathrm{C}$ and the reaction occurred in low $\mathrm{pH}$ value that favored $\mathrm{HOCl}$ as agent oxidant. The concentration of nitrite detected throughout the experiment was $0.045 \mathrm{mg} \mathrm{N} / \mathrm{L}, 0.032 \mathrm{mg} \mathrm{N} / \mathrm{L}$ and $0.023 \mathrm{mg} \mathrm{N} / \mathrm{L}$ at temperatures of $20^{\circ} \mathrm{C}, 30^{\circ} \mathrm{C}$ and $40^{\circ} \mathrm{C}$, respectively (Fig. 6). Simultaneously nitrate ions might come from indirect oxidation of $\mathrm{HOCl}$ and the hydroxyl radical. According to the results of research, $\mathrm{Cu} / \mathrm{Zn}$ was more suitable for the oxidation of ammonium. The highest formation of nitrate was also found with $\mathrm{Cu} / \mathrm{Zn}$ cathode and decreased finally with the time according to the standard discharge.
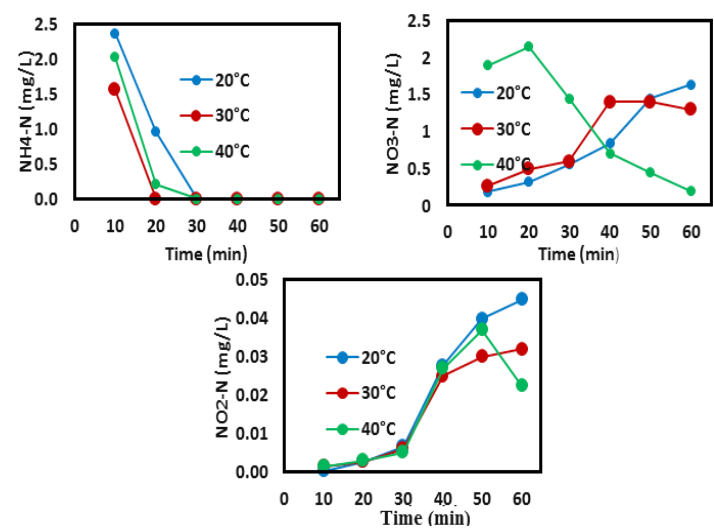

Fig. 6. Effect of Temperature on removal of ammonium using Cu/Zn electrode $\left(\mathrm{Co}=50 \mathrm{mg} / \mathrm{L} ; \mathrm{NaCl}=0.5 \mathrm{~g} / \mathrm{L} ; \mathrm{pH}=5.1 ; 16 \mathrm{~mA} / \mathrm{cm}^{2}\right)$

Treatment of real wastewater under optimal conditions

In this experiment, we used the influent of Tsinghua University Wastewater Treatment Plant, which consisted of domestic sewage wastewater from region of Beijing, without any pretreatment. The COD concentration of the raw sewage was $300 \mathrm{mg} / \mathrm{L}$ and the $\mathrm{NH}_{4}{ }^{+}-\mathrm{N}$ concentration was $90 \mathrm{mg} / \mathrm{L}$ (Table 1 ).

Table 1: Characteristics of real wastewater used

\begin{tabular}{ccc}
\hline Parameter & Unit & Value \\
\hline $\mathrm{pH}$ & - & 7.75 \\
Chemical oxygen demand (COD) & $\mathrm{mg} / \mathrm{L}$ & 300 \\
$\mathrm{NH}_{4}^{+}-\mathrm{N}$ & $\mathrm{mg} / \mathrm{L}$ & 90 \\
$\mathrm{PO}_{4}{ }^{--}$ & $\mathrm{mg} / \mathrm{L}$ & 5.5 \\
\hline
\end{tabular}

The alloy electrode of $\mathrm{Cu} / \mathrm{Zn}$ with a current density of $18.32 \mathrm{~mA} / \mathrm{cm}^{2}$, a space size between the two electrodes of $1.1 \mathrm{~cm}$, temperature of $40^{\circ} \mathrm{C}$ and an added amount of $0.5 \mathrm{~g} / \mathrm{L}$ of $\mathrm{NaCl}$, the raw sewage was electrolyzed, and the results are shown in (Fig. 7). The electrodes have an excellent effect on the removal rates of $\mathrm{COD}$ and $\mathrm{NH}_{4}{ }^{+}-\mathrm{N}$ from the raw 
sewage. After 30 min. of electrochemical reaction under the optimal conditions, the COD in raw sewage was $185 \mathrm{mg} / \mathrm{L}$, a removal rate of $38 \%$; and the total $\mathrm{NH}_{4}{ }^{+}-\mathrm{N}$ and $\mathrm{PO}_{4}{ }^{3-}$ concentration have removed.

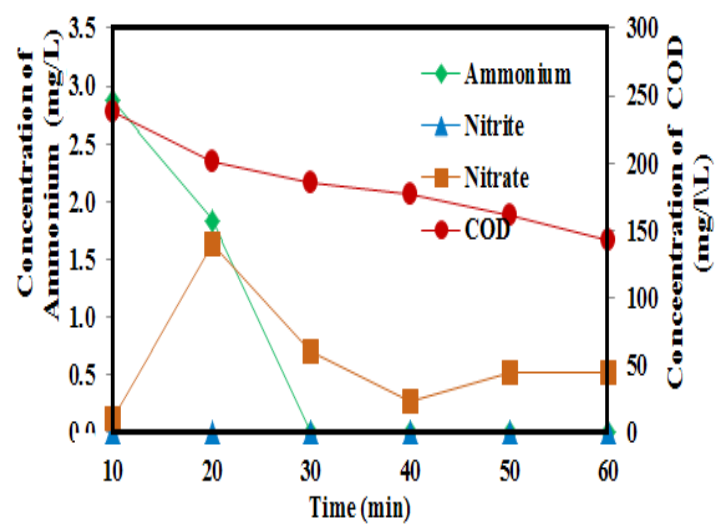

Fig. 7. Treatment of real wastewater under optimal condition

\section{Comparison among the electrodes}

The $\mathrm{Cu} / \mathrm{Zn}$ electrode is the most effective of all three electrodes used subsequently followed by the Fe electrode and finally the $\mathrm{Cu}$ electrode. The respective values of these three electrodes for reduction of ammonium without adding $\mathrm{NaCl}$ is $99.8 \%, 97.8 \%$ and $94.4 \%$ (Fig. 8). The process of oxidation of ammonium is a complex phenomenon. Conversion the ammonium to nitrite or nitrate is a reductive reaction. It must be recognized that conversion was mainly influenced by these electrodes using a cathode.

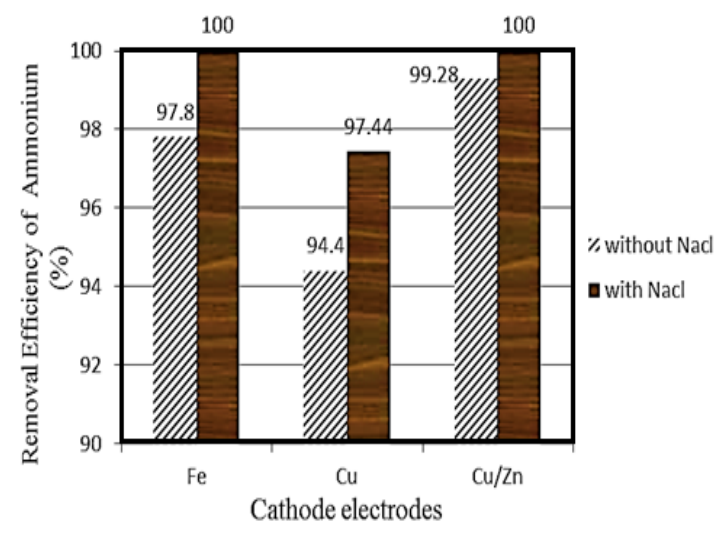

Fig. 8. Comparison among the electrodes ( $\mathrm{Cu}, \mathrm{Fe}$ and $\mathrm{Cu} / \mathrm{Zn})$

Nevertheless results reveal that the $\mathrm{Cu} / \mathrm{Zn}$ electrode has a higher yield for the reduction of ammonium because it has more effective properties in electro-catalytic but also has high over potential for hydrogen evolution in vicinity of cathode.
According to the result iron electrode is also very effective due its greater electron donating especially at low $\mathrm{pH}$. In our experiment, the $\mathrm{pH}$ of the solution before treatment was 5.6, whereas at high $\mathrm{pH}$ we found the phenomenon of passivation to the electrode surface area, which limited the oxidation process of ammonium.

Previous studied revealed $\mathrm{Cu} / \mathrm{Zn}$ electrode comparing to copper electrode was higher over potential. It seems that $\mathrm{Cu}$ electrode with more negative electrode inhibit the amount of hydrogen produced and finally limit the rate oxidation of ammonium.

\section{Degradation kinetic of $\mathrm{NH}_{4}^{+}-\mathrm{N}$}

The degradation kinetic of $\mathrm{NH}_{4}^{+}$was studied to examine the order of the reaction. Despite its complexity and it is being controlled by many interacting variables, we attempt to throw some light on the kinetics of the present process. It was assumed that the process takes place according to first order mechanism, which can be expressed by:

$\ln \left(\frac{C_{0}}{C_{t}}\right)=K t$

Where;

$\mathrm{C}_{\mathrm{o}}$ is the initial concentration ( $\left.\mathrm{mg} / \mathrm{L}\right), \mathrm{C}_{\mathrm{t}}$ is the concentration at time $t(\mathrm{mg} / \mathrm{L}), \mathrm{K}$ is the rate constant $\left(\min ^{-1}\right)$ and $t$ is the time (minute).

Figures 9 show the effect of current density $\left(16 \mathrm{~mA} / \mathrm{cm}^{2}\right)$, temperature $\left(20^{\circ} \mathrm{C}, 30^{\circ} \mathrm{C}\right.$, and $\left.40^{\circ} \mathrm{C}\right)$, $0.5 \mathrm{~g} / \mathrm{L}$ of $\mathrm{NaCl}, \mathrm{pH}$ value and initial concentration of ammonium (50mg N/L) on the kinetics of the reaction with Iron electrode as cathode. The present data agree with equation 1 (Eq.1), however, two (2) slopes are differentiated indicating the presence of two rates of removal. In first stage which occurs during few minutes, the rate is higher than the rate in second stage. The fast rate of removal in the first few minutes is attributed to the flocs which are still free so the adsorption rate is very fast. The low rate of removal in second stage is due to the fact that the flocs was reduced (the number of free flocs is few) so the adsorption rate becomes very slow. The presence of soluble iron in the solution and a high area of the working electrode iron facilitate the removal of $\mathrm{NH}_{4}^{+}-\mathrm{N}$ and denitrification. The difference between the electrode $\mathrm{Cu}$ and $\mathrm{Fe}$ electrode for ammonium removal is due to the number of electron giving. 


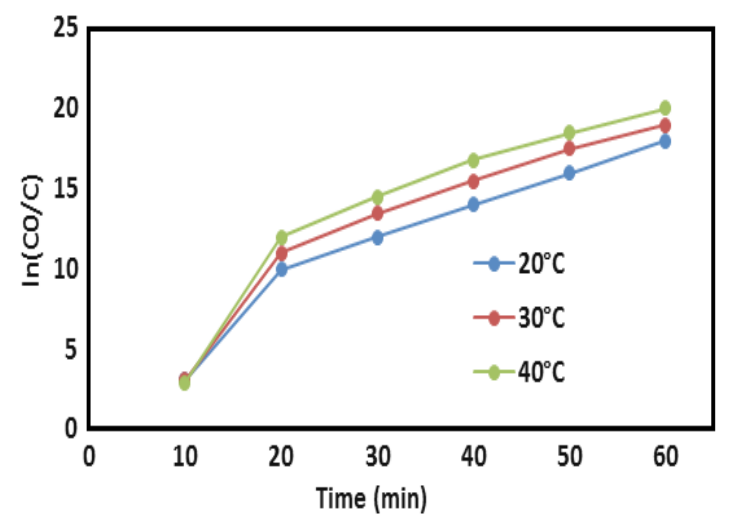

Fig. 9. Effect of temperature of ammonium on the kinetics of the reaction using iron electrode as cathode $(\mathrm{Co}=50$ $\mathrm{mg} / \mathrm{L} ; \mathrm{NaCl}=0.5 \mathrm{~g} / \mathrm{L} ; \mathrm{pH}=5.1 ; 16 \mathrm{~mA} / \mathrm{cm}^{2}$ )

\section{Mechanism and Reactions}

In the electrolytic, ammonium was eliminated with anodic electro-oxidation. Electrooxidation of ammonium occurred in two ways:

Ammonium was oxidized directly to the surface of the anode through the electrode such as $\mathrm{Ti} / \mathrm{IrO}_{2}-\mathrm{Pt}$.

Indirectly with the assistance of a mediator oxidation such as active chlorine $\mathrm{Cl}_{2}, \mathrm{HOCl}$, or $\mathrm{OCl}$ which were produced at the anode ${ }^{5,13}$. In indirect oxidation, chloride in the solution was oxidized to chlorine at the anode, and then the chlorine immediately reacted with $\mathrm{H}_{2} \mathrm{O}$ to form hypochlorite (HOCl) (Panizza and Cerisola, 2009) ${ }^{15}$ :

$$
\begin{aligned}
& 2 \mathrm{Cl}^{-} \rightarrow \mathrm{Cl}_{2}+2 \mathrm{e}^{-} \\
& \mathrm{Cl}_{2}+\mathrm{H}_{2} \mathrm{O} \rightarrow \mathrm{HOCl}+\mathrm{H}^{+}+\mathrm{Cl}^{-}
\end{aligned}
$$

Finally, ammonium was oxidized to nitrogen gas or nitrate through the electrochemically oxidants such as hypochlorus acid and hypochlorite ion in the vicinity of the anode. ${ }^{19,21}$

$$
\begin{aligned}
& 3 \mathrm{NH}_{4}^{+}+3 \mathrm{HClO} \rightarrow \mathrm{N}_{2}+3 \mathrm{H}_{2} \mathrm{O}+5 \mathrm{H}^{+}+\mathrm{Cl}^{-} \\
& \mathrm{NH}_{4}^{+}+4 \mathrm{HOCl} \rightarrow \mathrm{NO}_{3}^{-}+6 \mathrm{H}^{+}+4 \mathrm{Cl}^{-}+\mathrm{H}_{2} \\
& \text { Reduction: } \mathrm{NO}_{3}^{-} \rightarrow \mathrm{NO}_{2}^{-} \rightarrow \mathrm{N}_{2}
\end{aligned}
$$

The reducing environment in the electrochemical cell was influenced by the electrode material.

\section{CONCLUSION}

Electrochemical method for ammonium removal with $\mathrm{Cu}, \mathrm{Fe}$ and $\mathrm{Cu} / \mathrm{Zn}$ as cathode and $\mathrm{Ti} / \mathrm{IrO}_{2}$ as anode was considered as a good method. It appears that through the experiment $\mathrm{Cu} / \mathrm{Zn}$ electrode as cathode is better than $\mathrm{Fe}$ and $\mathrm{Cu}$ electrode for the ammonium removal with $\mathrm{NaCl}$ or without $\mathrm{NaCl}$. The high formation rate of nitrate without $\mathrm{NaCl}$ was found with $\mathrm{Cu} / \mathrm{Zn}$ and with $\mathrm{NaCl}$ addition it was $\mathrm{Cu}$ electrode as cathode. With the increase of the temperature, removal rate of ammonium improved on time specially with $\mathrm{Cu} / \mathrm{Zn}$ electrode around $30^{\circ} \mathrm{C}$ whereas the highest formation of nitrate was found with $\mathrm{Cu}$ around $30^{\circ} \mathrm{C}$. Electrochemical degradation of ammonium with the concentration of ammonium was studied follow the first-order model law. The kinetic study showed that current density (current passed used during experience per unit electrode area) is an appropriate design.

\section{ACKNOWLEDGEMENT}

The present study was funded by the 863 Program (2007AA06A410) of the Chinese Ministry of Science and Technology.

\section{Conflicts of Interest}

The authors declare no conflict of interest.

\section{REFERENCES}

1. APHA, Standard Methods for Examination of Water and Wastewater, American Public Health. Association, Washington., 1998, 87.

2. Arroyo M. G., V. P.-Herranz, M. T. Montanes, J. Garcia- Anton, and J. L.. Guinon, "Effect of $\mathrm{pH}$ and chloride concentration on the removal of hexavalent chromium in a batch electrocoagulation reactor", J. Hazard. Mater., 2009, 169(1-3), 1127-1133.

3. Chiang L. C., Chang J. E., Wen, T. C., Indirect oxidation effect in electrochemical oxidation treatment of landfill leachate. Water Research., 1995, 29(2), 671-678.
4. Deng Y, Englehardt J. D. Electrochemical oxidation for landfill leachate treatment [J]. Waste Management., 2007, 27(3), 380-388.

5. Ghafari S., M. Hasan, M. Aroua, Bioelectrochemical removal of nitrate from water and wastewater - a review, Bioresour. Technol., 2008, 99, 3965-3974.

6. Gupta S. K., Gupta A. B., Gupta R. C., Seth A. K., Bassain J. K., Gupta A. Recurrent acute respiratory tract infections in areas with high nitrate concentrations in drinking water. Environmental Health Perspectives., 2000, 108, 363-366. 
7. Kim K.W., Y.J. Kin, I.T. Kim, G. Park, E. Lee, Electrochemical conversion characteristics of ammonia to nitrogen, Water Res., 2006, 40, 1431-1441.

8. Kim T.H, Park C, Shin E.B. Decolorization of disperse and reactive dyes by continuous electrocoagulation process. J. Desalination., 2002, 150(2), 165-175.

9. Lee J.-K. Residual Chlorine Distribution and Disinfiction during Electrochemical Removal of Dilute Ammonia from an Aqueous Solution, J. Chem. Eng. Jpn., 2002, 35, 285.

10. Li L., LiuY.Ammonia removal in electrochemical oxidation: mechanism and pseudo-kinetics, $J$. Hazard. Mater., 2009, 161, 1010-1016.

11. Lin S.H, Wu C. L. Electrochemical removal of nitrite and ammonia for aquature. Water Res., 1996, 30(3), 715-721.

12. Martin $\mathrm{G}$. The problem of nitrogen in the water. Techniques and documentation., 1979, 657-659.

13. Mouedhen, G., Feki, M., Wery, M.D.P. and Ayedi, $\mathrm{H}$. Behavior of aluminum electrodes in electrocoagulation process. Journal of Hazardous Materials., 2008, 150(1), 124-135.

14. Nouri J., A.H.Mahvi, and E.Bazrafshan," Application of electrocoagulation process in removal of Zinc and Copper from Aqueous solutions by aluminum electrodes", Int. J. Environ., 2010, 4(2), 201-208.

15. Panizza M. and Cerisola G. Direct And Mediated Anodic Oxidation of Organic Pollutants Chemical Reviews., 2009, 109 (12), 6541-6569 DOI: 10.1021/cr9001319.

16. Pérez G., J. Saiz, R. Ibáñez, A.M. Urtiaga, I.
Ortiz, Assessment of the formation of oxidation by-products during the electrocatalytic treatment of ammonium from landfill leachates, Water Res., 2012a, 46, 2579-2590.

17. Pérez G., R. Ibáñez, A.M. Urtiaga, I. Ortiz Kinetic study of the simultaneous electrochemical removal of aqueous nitrogen compounds using BDD electrodes. Chemical Engineering Journal., 2012b, 197, 475-482

18. Rajic Lj, D. Berroa, S.Gregor, S. Elbakri, M.MacNeil, A. N. Alshawabkeh. Electrochemically-induced Reduction of Nitrate in Aqueous Solution., Int. J. Electrochem. Sci., 2017, 12, 5998-6009.

19. Reyter D., D. Bélanger, L. Roué, Nitrate removal by a paired electrolysis on copper and $\mathrm{Ti} / / \mathrm{rO}_{2}$ copled electrodes - influence of the anode/cathode surface area ratio, Water Res., 2010, 44, 1918-1926.

20. Shrimali M, Singh K P. New methods of nitrate removal from water[J]. Environmental pollution, 2001, 112(3), 351-359.

21. Vlyssides A.G., P.K. Karlis, N. Rori, A.A. Zorpas, Electrochemical treatment in relation to $\mathrm{pH}$ of domestic wastewater using Ti/Pt electrodes, J. Hazard. Mater., 2002, 95 215-226.

22. Wang Y., X. Guo, J. Li, Y. Yang, Z. Lei, Z. Zhang Efficient Electrochemical Removal of Ammonia with Various Cathodes and $\mathrm{Ti}^{\mathrm{RuO}}{ }_{2}-\mathrm{Pt}$ Anode Open Journal of Applied Sciences., 2012, 2, 241-247, doi:10.4236/ ojapps.2012.24036 